\title{
電場および各種外場環境下における動的挙動の解明 Understanding of Dynamic Behavior of Materials under Electric and Various External Fields
}

\author{
吉田 英弘 \\ Hidehiro YOSHIDA \\ 東京大学 \\ The University of Tokyo
}

各種材料における焼結緻密化や微細組織形成過程，あるい は光学特性や力学応答などの材料特性に対し, 電場, 磁場, 応力場, 光照射などの外場の印加が多大な影響を与えること が指摘されています。そこで, これら外場を積極的に利用し た新たな材料製造技術や材料開発，また新機能発現といった ことに期待が寄せられています．様々な外場効果を利用した 現象や合成技術に関する研究発表を通じて, 各種材料の動的 挙動に及ぼす外場効果についての基礎基盤的知見を総合し，

外場支援による新たなプロセスへと展開させるための議論を 一層深めたいという意図のもとに本講演特集を企画しまし た. その結果, 本特集では, 特別講演 2 件, 招待講演 2 件, 受賞講演 2 件および一般講演 11 件の全 17 件のご講演をいた だくことになりました．

今回の秋季大会は初めてのオンライン講演大会となり, 本 特集では全講演でオンデマンド動画配信を選択していただき ました. confitの動画配信システムの使い勝手の良さもあり, 各講演者には臨場感のあるご講演をしていただけました. 2 件の協会賞受賞記念講演では, それぞれ高磁場, 高電場を 利用したセラミックスの製造・開発に関する最近の研究成果 についてご紹介いただき，セラミックス製造技術のさらなる 高効率化だけでなく，従来技術では必ずしも実現できなかっ た微細組織制御が外場制御で可能となるということを示して いただけました，特別講演では外場制御によるセラミックス の高機能化とプロセスの革新についてご説明いただき，我が 国が進めるべき技術開発についてもご提案いただきました. また 2 件の招待講演では, 無機半導体の塑性変形に及ぼす光 環境効果およびフラッシュ焼結における材料の電気的応答に
ついての研究成果をご紹介いただき，電磁場印加による顕著 なセラミックスの動的挙動の変化についてご説明いただきま した. 一般講演では，セラミックス・ガラスを中心としたさ まざま材料において，その焼結プロセスや塑性流動，その他 材料の動的挙動に及ぼす外場効果についての新規知見が紹介 されました．セラミックスを始めとする無機材料は，外場の 働きによって, 室温での塑性変形や高速焼結, 高速超塑性と いった思いもよらないような動的挙動を示すことが実験的に 示されており, 今後の当該分野の発展が大いに期待されるこ とを改めて認識いたしました。

なお本講演大会における質疑応答では，聴講者に質問やコ メントを記載していただき，それに講演者が答えるという形 式となりましたが，いずれの講演にも多数の質問・コメント が寄せられ，幸いにして活発な議論がなされました。さら に，それぞれのコメントに対して講演者からの丁寧な回答が なされていたことは注目すべき点であり，これは時間的な余 裕をもって質疑応答がなされたことに起因すると推測されま

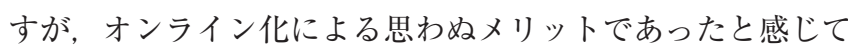
います。

本講演特集は, 初めてのオンライン講演大会にもかかわら ず，大勢の方に講演動画をご視聴いただくと共に，各講演に 多数の質問・コメントが寄せられ，非常に意義のある意見交 換ができました。この紙面をお借りして，本特集にご講演を いただきました方々ならびに活発なご議論を頂きました皆様, またオンライン大会の場をご準備いただきました事務局の皆 様に, 本講演特集の企画者として心より御礼申し上げます. 